John Carroll University Carroll Collected

Biology

$11-2010$

\title{
Variation in nutrient resorption by desert shrubs
}

Rebecca E. Drenovsky

John Carroll University, rdrenovsky@jcu.edu

Jeremy J.James

James H. Richards

Follow this and additional works at: http://collected.jcu.edu/biol-facpub

Part of the Biology Commons, and the Plant Sciences Commons

\section{Recommended Citation}

Drenovsky, Rebecca E.; James, Jeremy J.; and Richards, James H., "Variation in nutrient resorption by desert shrubs" (2010). Biology. 19.

http://collected.jcu.edu/biol-facpub/19

This Article is brought to you for free and open access by Carroll Collected. It has been accepted for inclusion in Biology by an authorized administrator of Carroll Collected. For more information, please contact connell@jcu.edu. 
Short Communication

\title{
Variation in nutrient resorption by desert shrubs
}

\author{
Rebecca E. Drenovsky ${ }^{\mathrm{a}, *}$, Jeremy J. James ${ }^{\mathrm{b}}$, James H. Richards ${ }^{\mathrm{c}}$ \\ ${ }^{a}$ Biology Department, John Carroll University; 20700 North Park Blvd, 44118, University Heights, OH, USA \\ ${ }^{\mathrm{b}}$ USDA-Agricultural Research Service, Eastern Oregon Agricultural Research Center, 67826-A Hwy 205, Burns, OR 97720, USA \\ ${ }^{\mathrm{c}}$ Department of Land, Air, and Water Resources; University of California; Davis, CA, 95616-8627; USA
}

\section{Keywords:}

Drought

Phylogenetic comparison

Resorption proficiency

Senesced leaf nitrogen

Senesced leaf phosphorus

Salinity

\begin{abstract}
A B S T R A C T
Plant nutrient resorption prior to leaf senescence is an important nutrient conservation mechanism for aridland plant species. However, little is known regarding the phylogenetic and environmental factors influencing this trait. Our objective was to compare nitrogen $(\mathrm{N})$ and phosphorous $(\mathrm{P})$ resorption in a suite of species in the Asteraceae and Chenopodiaceae and assess the impact of soil salinity on nitrogen resorption. Although asters and chenopods did not differ in $\mathrm{N}$ resorption proficiency, chenopods were more proficient than asters at resorbing P. Plant responses to salinity gradients were species-specific and likely related to different salt-tolerances of the species. During the three year study, precipitation varied 6.4- and 9.9-fold from the long term averages at our two desert sites; despite these differences, annual variation in nutrient resorption was not linked to annual precipitation. More detailed studies are required to understand the influence of salinity and precipitation on resorption. Understanding controls on this trait may give insight into how species will respond to anthropogenic soil salinization and desertification.
\end{abstract}

In arid, nitrogen and phosphorus-limited systems, plant performance depends on nutrient conservation. During leaf senescence, plants break down biomolecules and translocate nutrients to storage tissues. This process (resorption) is considered one of the most important plant nutrient conservation mechanisms (Eckstein et al., 1998; Killingbeck, 1996; van Heerwaarden et al., 2003). In aridlands, resorption may be particularly important to whole-plant nutrient budgets due to slow decomposition rates and variable soil nutrient supply (Noy-Meir, 1973). Comparing data from seven desert shrubs to average values for non-desert shrubs, resorption was higher in desert species, suggesting tight internal nutrient recycling is key in arid habitats (Killingbeck, 1993). Despite its significance, there is little information examining phylogenetic and environmental controls influencing resorption in aridland species. Such understanding is fundamental for predicting plant community responses to anthropogenic disturbance as well as understanding selection pressures leading to variation in this trait.

Resorption potential is not a simple function of habitat nutrient availability. Instead, resorption may be influenced by phylogeny and/or environmental factors, including both drought and salinity stress (Killingbeck, 1996). Some research suggests resorption may be more similar among closely related than distantly related

\footnotetext{
* Corresponding author. Tel.: +1 2163974451.

E-mail address: rdrenovsky@jcu.edu (R.E. Drenovsky).
}

species (Killingbeck, 1996; Wright and Westoby, 2003); however, resorption varied greatly in some congeners, suggesting evolutionary history is not the only factor driving resorption (Killingbeck, 1996). Despite the predicted importance of resorption in arid systems, little research has focused on this trait in arid environments. Both drought (Bertiller et al., 2005; Wright and Westoby, 2003) and soil salinity (Drenovsky and Richards, 2006) may decrease resorption, due to rapid leaf senescence and the need for $\mathrm{N}$-rich compatible solute accumulation in leaves (e.g., glycinebetaine). Desert systems thus provide a unique test of environmental constraints on resorption, as they are water-limited and often saline.

Our objective was to compare nitrogen (N) and phosphorus (P) resorption in widely distributed desert shrubs from two families (Asteraceae and Chenopodiaceae) and to determine the effects of soil salinity on resorption. Previous data suggested that the aster, Chrysothamnus nauseosus ssp. consimilis, was more proficient at $\mathrm{N}$, but not $\mathrm{P}$, resorption, compared to the chenopod, Sarcobatus vermiculatus (Drenovsky and Richards, 2006). These differences were attributed to their relative requirement for $\mathrm{N}$-containing compatible solutes for drought and salinity tolerance (C. nauseosus ssp. consimilis is less drought and salinity tolerant than $S$. vermiculatus) and their mycorrhizal status (C. nauseosus ssp. consimilis is mycorrhizal, S. vermiculatus is not) (Drenovsky and Richards, 2004). Based on these two model species, we hypothesized that asters would resorb more $\mathrm{N}$ but less $\mathrm{P}$ than chenopods. To examine the influence 
of soil salinity on resorption, we sampled a subset of species growing along natural salinity gradients. We hypothesized that $\mathrm{N}$ concentration in senesced leaf tissue would increase as soil salinity increased due to compatible solute accumulation but that these responses would depend, in part, on the salt tolerance of the species.

Our study was conducted at the Mono Basin Ecosystem Research Site (MBERS), near Mono Lake, and around the Owens Lake playa, California, USA during Fall 2005, 2006, and 2007. MBERS is located on the western edge of the Great Basin Desert, USA, and the Owens playa is on the northern edge of the Mojave Desert, USA. Vegetation at both sites is dominated by shrubs in the Asteraceae and Chenopodiaceae. Annual precipitation at MBERS averages $160 \mathrm{~mm}$ (Snyder et al., 2004). During our study, precipitation varied 6.4-fold (2005: $289 \mathrm{~mm}$; 2006: $416 \mathrm{~mm}$; 2007: $65 \mathrm{~mm}$ ); precipitation was determined from records at Cain Ranch $(24 \mathrm{~km}$ from the study area). Average annual rainfall around the Owens playa is $149 \mathrm{~mm}$ (Snyder et al., 2004); during our study, precipitation varied 9.9-fold (2005: $200.0 \mathrm{~mm}$; 2006: $75.6 \mathrm{~mm}$; 2007: $20.3 \mathrm{~mm}$ ). Precipitation was determined from the average of two Owens Lake CIMIS weather stations (http://www.cimis.water.ca.gov/cimis/welcome. jsp).

Both systems are closed hydrologic basins that have experienced natural and anthropogenic lake level change. MBERS is composed of a series of dunes representing previous shorelines. Old Growth Dunes and Diverse Dunes represent shorelines exposed due to natural climatic changes. These sites have lower soil $\mathrm{pH}$, lower soil salinity, and higher plant diversity than Sand Shadow Dunes, which are closer to Mono Lake and represent a shoreline exposed due to water diversion for urban use (Aanderud et al., 2008; Donovan et al., 1997; Toft and Elliott-Fisk, 2002). The Owens playa also represents both ancient and recent shorelines, as well as exposed lakebed; Owens Lake has been dried completely since 1926 due to re-routing of tributary waters to urban areas (Saint-Amand et al., 1986). Similar to MBERS, upland sites are lower in soil $\mathrm{pH}$ and salinity and higher in plant diversity than playa sites (Dahlgren et al., 1997). Both sites are periodically grazed by cattle, and most asters are grazed by herbivorous mammals, predominantly jackrabbits. At MBERS and the Owens playa, we sampled a total of seven aster species (MBERS: Artemisia tridentata, Chrysothamnus nauseosus ssp. albicaulis, C. nauseosus ssp. consimilis, Chrysothamnus viscidiflorus, Tetradymia glabrata, Tetradymia tetrameres; Owens playa: Artemisia spinescens, A. tridentata) and six chenopods (MBERS: Atriplex canescens, Atriplex confertifolia, S. vermiculatus; Owens playa: A. canescens, A. confertifolia, Atriplex hymenelytra, Atriplex parryi, Sarcobatus baileyi, S. vermiculatus) in low salinity, high diversity areas and select asters and chenopods that could be found at multiple locations along salinity gradients (C. nauseosus ssp. consimilis, C. viscidiflorus, A. parryi, and S. vermiculatus). Nomenclature follows that of the Jepson Manual (Hickman, 1993). Adult shrubs of similar size were randomly selected. Due to strong winds, no senesced leaves were available from A. parryi during 2007 at the high salinity site. All sampled genera include species varying in salinity tolerance based upon their relative dominance along salinity gradients and previous experimental work (Donovan and Richards, 2000; Richards, 1994).

Senescent leaves were collected by gently shaking branches. Each year, 3-7 shrubs per species were sampled. Different shrubs were sampled each year. Prior to analysis, leaves were dried at $60{ }^{\circ} \mathrm{C}$, triple-rinsed in deionized water to remove surface salts and dust, dried again at $60^{\circ} \mathrm{C}$, and finely ground. Leaf $\mathrm{N}$ was analyzed on a $\mathrm{CN}$ analyzer. Leaf $\mathrm{P}$ was measured by ICP-AES on dry-ashed samples suspended in $1 \mathrm{~N} \mathrm{HCl}$. We used $\mathrm{N}$ and $\mathrm{P}$ resorption proficiency, the $\mathrm{N}$ or $\mathrm{P}$ concentration in senesced leaf tissue, as our measure of resorption ( $\mathrm{N}_{\mathrm{PROF}}$ and $\mathrm{P}_{\mathrm{PROF}}$, respectively; Drenovsky and
Richards, 2006; Killingbeck, 1996). Lower values represent less nutrient loss from the plant and thus, high proficiency.

During November 2007, three soil subsamples (0-30 cm depth to represent the main rooting zone) were collected below the canopy dripline of each shrub $(n=3-4$ shrubs per species per sampling site). Subsamples were composited, air-dried, and sieved (2 mm). Total $\mathrm{N}$ was measured on a $\mathrm{CN}$ analyzer, and Olsen's extractable $\mathrm{P}$ was measured by flow injection analysis. Soil $\mathrm{pH}$ and electrical conductivity (E.C.) was measured on 1:5 soil-water extracts.

To address hypothesis one, we compiled data from seven asters and six chenopods from high diversity, low salinity sites. We used a randomized block design in which we pooled annual data from individual shrubs of each species. Sampling year was the block factor, and the main effect was family (Asteraceae or Chenopodiaceae). To address hypothesis two, we analyzed $\mathrm{N}_{\text {PRoF }}$ data from two asters (C. nauseosus ssp. consimilis and $C$. viscidiflorus) and two chenopods (A. parryi and S. vermiculatus) that grow along salinity gradients. In this analysis, the main effects were site and block; sampling year was the block factor. Data were analyzed with SAS (SAS, 2002).

Total soil $\mathrm{N}$ did not differ between aster and chenopod soil microsites $(P=0.44$; Table 1$)$, but extractable soil $P$ was higher in aster compared to chenopod soil microsites $(P=0.04$; Table 1$)$. Soil $\mathrm{pH}$ and E.C. were lower in aster compared to chenopod microsites $(P=0.0003$ and $P=0.0015$, respectively; Table 1$)$. At MBERS, total soil N increased over 3.3-fold with substrate age $(P=0.0015$; Table 1 ). Around the Owens playa, soil $\mathrm{N}$ was 5.2 -fold higher at the Upland site compared to the Playa site $(P=0.005$; Table 1$)$. Extractable soil $P$ increased 3.4-fold with substrate age at MBERS $(P=0.03$; Table 1$)$, but it did not differ among soils from around the Owens playa $(P=0.39$; Table 1$)$. Soil $\mathrm{pH}$ and E.C. decreased with substrate age at both MBERS $(P=0.0002$ and $P<0.0001$, respectively; Table 1$)$ and around the Owens playa $(P=0.01$ and $P=0.03$, respectively; Table 1 ).

$\mathrm{N}_{\mathrm{PROF}}$ did not differ between asters and chenopods $(P=0.27$; Fig. 1A). In contrast, $P_{\mathrm{PROF}}$ was 4.3 -fold higher in asters than chenopods $(P=0.015$; Fig. $1 \mathrm{~B})$. $\mathrm{N}_{\mathrm{PROF}}$ varied 1.5 -fold among sampling years $(P=0.0012$; Fig. $1 \mathrm{~A})$ but was similar among years for $\mathrm{P}_{\mathrm{PROF}}$ $(P>0.05)$.

$\mathrm{N}_{\text {PROF }}$ did not differ between sites varying in salinity for either C. viscidiflorus $(P=0.79$; Fig. $2 \mathrm{~A})$ or $C$. nauseosus ssp. consimilis $(P=0.53$; Fig. $2 B)$. Year was not a significant factor for $C$. viscidiflorus $(P=0.26$; Fig. $2 \mathrm{~A})$ but was for $C$. nauseosus ssp. consimilis $(P=0.0007$; Fig. $2 \mathrm{~B}) . \mathrm{N}_{\mathrm{PROF}}$ significantly differed between sites for both chenopods, but species responses were in opposite directions. Across all years, $\mathrm{N}_{\mathrm{PROF}}$ was 1.4 -fold higher for $S$. vermiculatus at Sand Shadow Dunes (higher salinity site) than at Old Growth Dunes (lower salinity site) $(P=0.0017$; Fig. $2 \mathrm{C})$. For $A$. parryi, $\mathrm{N}_{\mathrm{PROF}}$ was 1.9 -

Table 1

Soil chemistry $(0-30 \mathrm{~cm})$ associated with different shrub microsites (aster and chenopod microsites, as well as different sampling locations along the salinity gradient at MBERS and around the Owens playa). Data are means $\pm \operatorname{SE}(n=6-7$ for family microsites; $n=3-15$ for MBERS and Owens Valley microsites).

\begin{tabular}{lcrrr}
\hline Shrub microsite & $\mathrm{N}\left(\mathrm{g} \mathrm{kg}^{-1}\right)$ & $\mathrm{P}\left(\mathrm{mg} \mathrm{kg}^{-1}\right)$ & \multicolumn{1}{c}{$\mathrm{pH}$} & $\left.\mathrm{E} . \mathrm{C} .(\mathrm{dS} \mathrm{m})^{-1}\right)$ \\
\hline Family & & & & \\
Asteraceae & $0.49 \pm 0.09$ & $25.4 \pm 7.5$ & $8.4 \pm 0.3$ & $0.23 \pm 0.06$ \\
Chenopodiaceae & $0.39 \pm 0.07$ & $6.5 \pm 1.8$ & $9.9 \pm 0.1$ & $0.59 \pm 0.06$ \\
MBERS & & & & \\
Old Growth Dunes & $0.67 \pm 0.07$ & $33.2 \pm 5.8$ & $8.5 \pm 0.2$ & $0.44 \pm 0.10$ \\
$\begin{array}{l}\text { Diverse Dunes } \\
\text { Sand Shadow Dunes }\end{array}$ & $0.40 \pm 0.03$ & $17.2 \pm 3.2$ & $9.4 \pm 0.1$ & $0.43 \pm 0.08$ \\
$\begin{array}{l}\text { Owens Valley } \\
\text { Upland }\end{array}$ & $0.20 \pm 0.0$ & $9.6 \pm 2.0$ & $10.4 \pm 0.1$ & $4.72 \pm 1.49$ \\
Playa & $0.52 \pm 0.08$ & $4.9 \pm 2.7$ & $9.8 \pm 0.1$ & $0.63 \pm 0.04$ \\
\hline & $0.1 \pm 0.0$ & $7.9 \pm 1.7$ & $10.0 \pm 0.0$ & $2.18 \pm 0.99$ \\
\hline
\end{tabular}




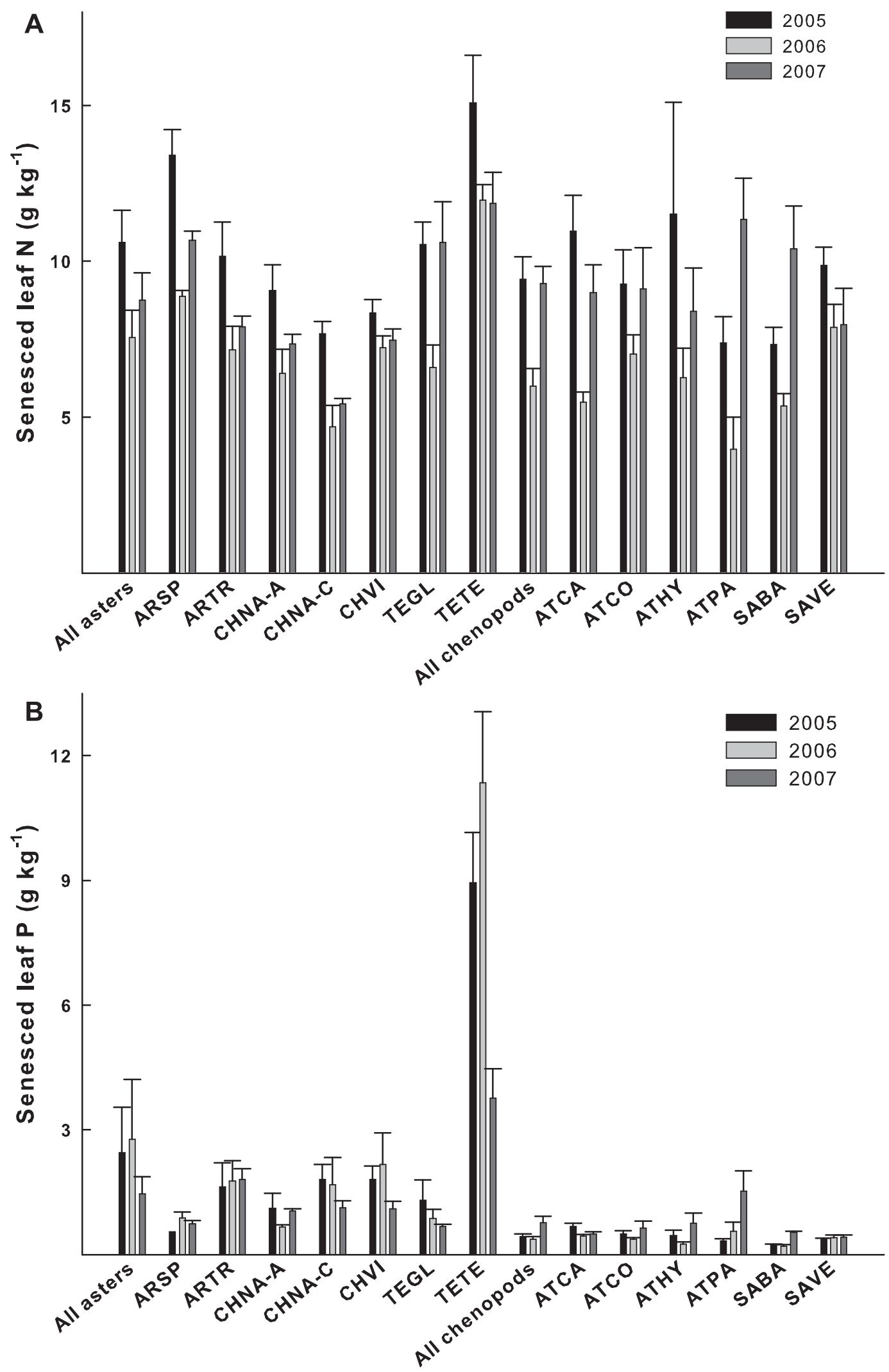

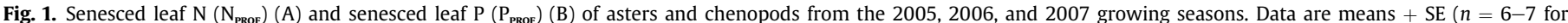

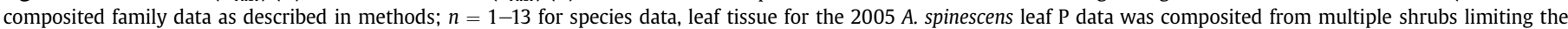

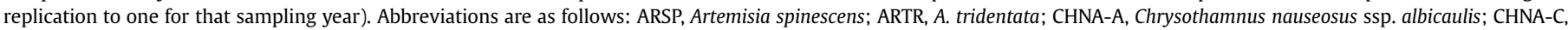

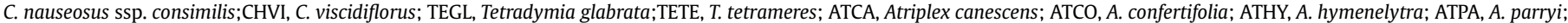
SABA, Sarcobatus baileyi; SAVE, S. vermiculatus). 

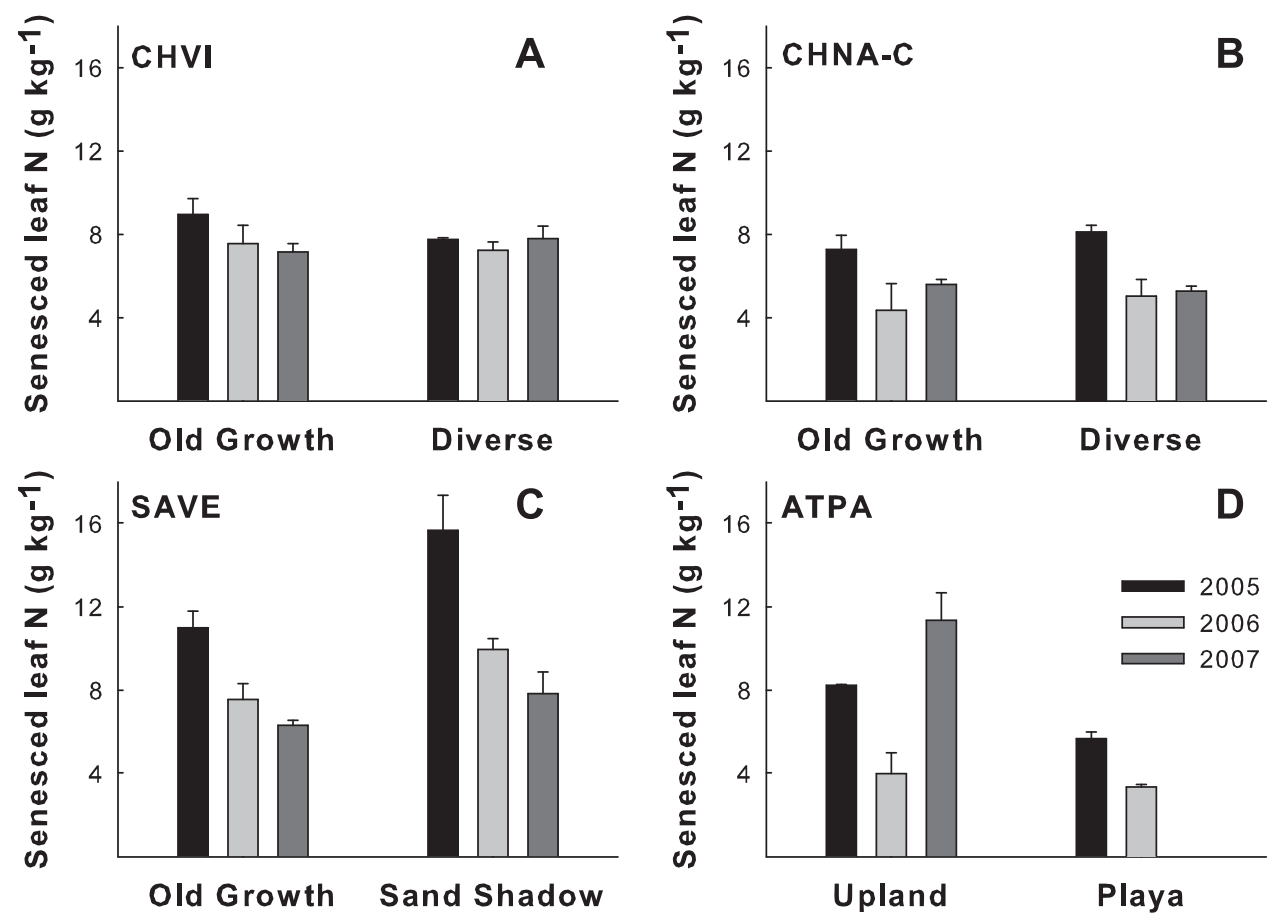

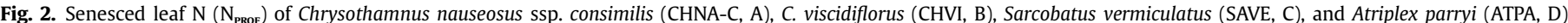

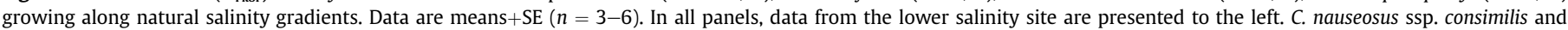

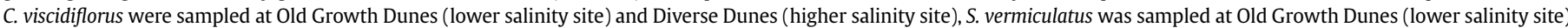

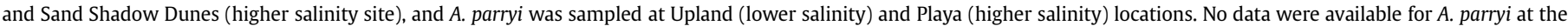
high salinity site in 2007.

fold higher at the Upland site (lower salinity site) than at the Playa site (higher salinity site) $(P=0.0002$; Fig. 2D). Year was significant for S. vermiculatus $(P<0.0001$; Fig. $2 C)$ and $A$. parryi $(P=0.0002$; Fig. 2D).

In support of our first hypothesis, $\mathrm{P}_{\mathrm{PROF}}$ varied significantly between asters and chenopods. These results extend previous observations of $C$. nauseosus ssp. consimilis and $S$. vermiculatus, in which the aster was less proficient at resorbing $\mathrm{P}$ than the chenopod. Unlike asters, chenopods either do not form functional mycorrhizal relationships or are only weakly mycorrhizal (Allen and Allen, 1990). Combined with very low soil $P$ at these sites, there is a strong selection pressure for highly proficient $\mathrm{P}$ resorption in chenopods. Comparing chenopod $\mathrm{P}_{\mathrm{PROF}}$ from this study to published literature results, in 2005 and 2006, the chenopods completely resorbed $\mathrm{P}$ (sensu Killingbeck, 1996), and in 2007, $\mathrm{P}_{\mathrm{PROF}}$ was just above the complete resorption range. Although $\mathrm{P}_{\mathrm{PROF}}$ was highly variable among asters, it was well above the incomplete range (>0.8 $\mathrm{g} \mathrm{kg}^{-1}$; sensu Killingbeck, 1996) in all years sampled. In Andean-Patagonian trees there was a correlation between mycorrizal colonization (and thus adequate $P$ supply) and poor $P_{\mathrm{PROF}}$ (Diehl et al., 2008). In contrast to their work, despite its mycorrhizal status, at least one of the asters included in this study is co-limited by P and water (Drenovsky and Richards, 2004). Given the importance of resorption in nutrient conservation, our data suggest other factors may limit P resorption in these desert asters. Artemisia, Chysothamnus, and Tetradymia species produce a variety of secondary compounds, including terpenes (Hegazy et al., 2007; Jennings et al., 1974; Kelsey et al., 1982; Personius et al., 1987), the intermediates of which require phosphate (Croteau et al., 2000). It is possible that these compounds preclude more proficient $\mathrm{P}$ resorption.

In contrast with $\mathrm{P}_{\mathrm{PROF}}, \mathrm{N}_{\mathrm{PROF}}$ did not vary between families. Previous research comparing resorption in C. nauseosus ssp. consimilis and $S$. vermiculatus indicated the aster, $C$. nauseosus ssp. consimilis, was more proficient at resorbing $\mathrm{N}$ than the salt-accumulating chenopod, S. vermiculatus (Drenovsky and Richards, 2006). As salts accumulate in leaf vacuoles, compatible solutes are synthesized in the cytoplasm, in part, to maintain cellular water relations (Bartels and Sunkar, 2005). Since functional cells are necessary for nutrient export, we hypothesized that the salttolerant chenopods, due to compatible solute accumulation, would have a smaller potential pool of resorbable $\mathrm{N}$ than the relatively more salt sensitive asters. However, even within the chenopods, there is a range of salt tolerance (Reimann and Breckle, 1993). These differences may influence the size of the compatible solute pool and thus the amount of potentially resorbable $\mathrm{N}$, masking any trend between $\mathrm{N}_{\mathrm{PROF}}$ and salt tolerance.

$\mathrm{N}_{\text {PROF }}$ responses of $A$. parryi and $S$. vermiculatus along salinity gradients were in opposite directions. A. parryi had lower, and $S$. vermiculatus had higher, senesced leaf $\mathrm{N}$ at their respective high salinity sites. As a $\mathrm{C}_{4}$ species, $A$. parryi has lower $\mathrm{N}$ requirements than $S$. vermiculatus, a $C_{3}$ species; thus, green leaf $\mathrm{N}$ concentrations, and subsequently senescent leaf $\mathrm{N}$ concentrations should be lower in A. parryi (Lambers et al., 2008). Additionally, A. parryi grows on extremely $\mathrm{N}$ poor soils at the high salinity site; previously measured green leaf concentrations were similar to the senescent leaf concentrations observed in this study (James et al., 2005). Therefore, there may be little non-structural $\mathrm{N}$ that can be resorbed in this species at this site. In contrast, high leaf $\mathrm{N}$ has been measured in Sarcobatus at more saline sites (Drenovsky and Richards, 2005), providing a larger pool of potentially resorbable $\mathrm{N}$.

$\mathrm{N}_{\text {PROF }}$ was similar at the lower and higher salinity sites for both asters (C. nauseosus ssp. consimilis and C. viscidiflorus). Although C. nauseosus ssp. consimilis is moderately salt-tolerant, neither species likely accumulated sufficient leaf salt to necessitate extensive compatible solute accumulation. Additionally, the difference in salinity between sites may have been insufficient to observe any 
significant effect on resorption. Little difference in soil E.C. was observed in this study between Diverse and Old Growth Dunes, although differences between these sites have been detected in previous work (Aanderud et al., 2008). More detailed studies under controlled conditions are necessary to parse out effects of salinity, salt tolerance, and resorption.

Although our study was not designed to address the effect of water availability on resorption, it encompassed both above and below average rainfall years. Despite this variation, we did not observe any correlation between precipitation and resorption. Some researchers have noted poorer resorption at drier sites or under water-stressed conditions (Bertiller et al., 2005; Wright and Westoby, 2003), while other authors have observed no relationship (Diehl et al., 2008) or a negative relationship (Lajtha, 1987) between these variables. These discrepancies may be related to differences in soil texture, which influence infiltration rates and water holding capacity. Additionally, if plants can root to groundwater, resorption processes may continue unaffected, even while surface soils dry. More detailed studies are necessary to understand relationships between soil water availability, plant morphology, and resorption processes.

Our research suggests both phylogeny and salinity influence nutrient resorption in aridland asters and chenopods. These data suggest it may be difficult to predict, at the family-level, species responses to environmental perturbations and stressors. However, some inferences may be made based on specific physiological traits (e.g., level of salinity tolerance). Additionally, low-nutrient adapted species may be limited by the amount of non-structural $\mathrm{N}$ that can be recycled. Future work should focus on the role of nutrient resorption in whole-plant nutrient budgets, as well as controlled greenhouse studies, in which soil nutrients are not limiting but soil salinity or moisture varies. Understanding links between plant nutrient budgets, soil salinity, drought, and resorption may help us better predict species responses to anthropogenic soil salinization and desertification.

\section{Acknowledgements}

We thank W. Collatz, M. Jorgensen, M. Krautova, B. Lazarus, and E. Sharp for field help; M. Falasco, A. Martin, C. Martin, S. Mudery, and E. Wygant for sample preparation; M. Setter for help with ICP analysis; and C. Rodrigues of LADWP for Cain Ranch precipitation data. A Franklin Research Grant from the American Philosophical Society and the California Agricultural Experiment Station funded this work.

\section{References}

Aanderud, Z.T., Shuldman, M.I., Drenovsky, R.E., Richards, J.H., 2008. Shrub-interspace dynamics alter relationships between microbial community composition and belowground ecosystem characteristics. Soil Biology and Biochemistry 40, 2206-2216.

Allen, M.F., Allen, E.B., 1990. Carbon source of VA mycorrhizal fungi associated with Chenopodiaceae from a semi-arid shrub-steppe. Ecology 71, 2019-2021.

Bartels, D., Sunkar, R., 2005. Drought and salt tolerance in plants. Critical Reviews in Plant Sciences 24, 23-58.

Bertiller, M.B., Sain, C.L., Carrera, A.L., Vargas, D.N., 2005. Patterns of nitrogen and phosphorus conservation in dominant perennial grasses and shrubs across an aridity gradient in Patagonia, Argentina. Journal of Arid Environments 62, 209-223.
Croteau, R., Kutchan, R.M., Lewis, N.G., 2000. Natural products (secondary metabolites). In: Buchanan, B.B., Gruissem, W., Jones, R.L. (Eds.), Biochemistry and Molecular Biology of Plants. American Society of Plant Physiologists, Rockville, MD, pp. 1250-1318.

Dahlgren, R.A., Richards, J.H., Yu, Z., 1997. Soil and groundwater chemistry and vegetation distribution in a desert playa, Owens Lake, California. Arid Soil Research and Rehabilitation 11, 221-244.

Diehl, P., Mazzarino, M.J., Fontenla, S., 2008. Plant limiting nutrients in AndeanPatagonian woody species: effects of interannual rainfall variation, soil fertility, and mycorrhizal infection. Forest Ecology and Management 255, 2973-2980.

Donovan, L.A., Richards, J.H., 2000. Juveniles show differences in stress tolerance, but no competition or facilitation, along a stress gradient. Journal of Ecology 88 $1-16$.

Donovan, L.A., Richards, J.H., Schaber, E.J., 1997. Nutrient relations of the halophytic shrub, Sarcobatus vermiculatus, along a soil salinity gradient. Plant and Soil 190 105-117.

Drenovsky, R.E., Richards, J.H., 2004. Critical N: P values: Predicting nutrient deficiencies in desert shrublands. Plant and Soil 259, 59-69.

Drenovsky, R.E., Richards, J.H., 2005. Nitrogen addition increases fecundity in the desert shrub, Sarcobatus vermiculatus. Oecologia 143, 349-356.

Drenovsky, R.E., Richards, J.H., 2006. Low leaf N and P resorption contributes to nutrient limitation in two desert shrubs. Plant Ecology 183, 305-314.

Eckstein, R.L., Karlsson, P.S., Weih, M., 1998. The significance of resorption of leaf resources for shoot growth in evergreen and deciduous woody plants from a subarctic environment. Oikos 3, 567-575.

Hegazy, M.E.F., Mohamed, A.E.H.H., El-Razek, M.H.A., Hammouda, F.M., Hassan, N.M., Mahaleld, U.A., El-Halawanye, A.M., Mahmoud, A.A., Karchesy, J., Hirata, T., Ahmed, A.A., 2007. Genus Chrysothamnus: A source of bioactive compounds, vol. 2. Natural Product Communications. 951-957.

Hickman, J.C. (Ed.), 1993. The Jepson Manual: Higher Plants of California. University of California Press, Berkeley, CA, pp. 1400

James, J.J., Tiller, R.L., Richards, J.H., 2005. Multiple resources limit plant growth and function in a saline-alkaline desert community. Journal of Ecology 93, 113-126.

Jennings, P.W., Reeder, S.K., Hurley, J.C., Caughlan, C.N., Smith, G.D., 1974. Isolation and structure determination of one of the toxic constituents from Tetradymia glabrata. Journal of Organic Chemistry 39, 3392-3398.

Kelsey, R.G., Stephens, J.R., Shafizadeh, F., 1982. The chemical constituents of sagebrush foliage and their isolation. Journal of Range Management 35, 617-622.

Killingbeck, K.T., 1993. Nutrient resorption in desert shrubs. Revista Chilena de Historia Natural 66, 345-355.

Killingbeck, K.T., 1996. Nutrients in senesced leaves: keys to the search for potential resorption and resorption proficiency. Ecology 77, 1716-1727.

Lajtha, K., 1987. Nutrient reabsorption efficiency and the response to phosphorus fertilization in the desert shrub Larrea tridentata (DC.) Cov. Biogeochemistry 4, 265-276.

Lambers, H., Chapin, F.S., Pons, T.L., 2008. Plant Physiological Ecology, second ed. Springer, Berlin, pp. 604.

Noy-Meir, I., 1973. Desert ecosystems: environment and producers. Annual Review of Ecology and Systematics 5, 25-51.

Personius, T.L., Wambolt, C.L., Stephens, J.R., Kelsey, R.G., 1987. Crude terpenoid influence on mule deer preference for sagebrush. Journal of Range Management 40, 84-88.

Reimann, C., Breckle, S.W., 1993. Sodium relations in Chenopodiaceae: a comparative approach. Plant Cell and Environment 16, 323-328.

Richards, J.H., 1994. Physiological limits of plants in desert playa environments Land, Air and Water Resources Paper 100026. University of California, Davis, 86 pp.

Saint-Amand, P., Mathews, L.A., Gaines, C., Reinking, R., 1986. Dust storms from Owens and Mono Valleys, California. NWC-TP 6731. Naval Weapons Center, China Lake, California.

SAS Institute, 2002. SAS/STAT User's Guide v9.1. SAS Institute, Cary.

Snyder, K.A., Donovan, L.A., James, J.J., Tiller, R.L., Richards, J.H., 2004. Extensive summer water pulses do not necessarily lead to canopy growth of Great Basin and northern Mojave Desert shrubs. Oecologia 141, 325-334.

Toft, C.A., Elliott-Fisk, D., 2002. Patterns of vegetation along a spatiotemporal gradient on shoreline strands of a desert basin lake. Plant Ecology 158, 21-39.

van Heerwaarden, L.M., Toet, S., Aerts, R., 2003. Nitrogen and phosphorus resorption efficiency and proficiency in six sub-arctic bog species after 4 years of nitrogen fertilization. Journal of Ecology 91, 1060-1070.

Wright, I.J., Westoby, M., 2003. Nutrient concentration, resorption and lifespan: Leaf traits of Australian sclerophyll species. Functional Ecology 17, 10-19. 